\title{
Effects of mountain tea plantations on nutrient cycling at upstream watersheds
}

\author{
T.-C. Lin ${ }^{1}$, P.-J. L. Shaner ${ }^{1}$, L.-J. Wang ${ }^{2}$, Y.-T. Shih ${ }^{3}$, C.-P. Wang ${ }^{4}$, G.-H. Huang ${ }^{1}$, and J.-C. Huang ${ }^{3}$ \\ ${ }^{1}$ Department of Life Science, National Taiwan Normal University, 11677 Taipei, Taiwan \\ ${ }^{2}$ Department of Forestry, National Taiwan University, 10617 Taipei, Taiwan \\ ${ }^{3}$ Department of Geography, National Taiwan University, 10617 Taipei, Taiwan \\ ${ }^{4}$ Taiwan Forestry Research Institute, Taipei, 10066 Taipei, Taiwan \\ Correspondence to: J.-C. Huang (riverhuang@ ntu.edu.tw)
}

Received: 28 March 2015 - Published in Hydrol. Earth Syst. Sci. Discuss.: 4 May 2015

Revised: 12 September 2015 - Accepted: 27 October 2015 - Published: 9 November 2015

\begin{abstract}
The expansion of agriculture to rugged mountains can exacerbate negative impacts of agricultural activities on ecosystem function. In this study, we monitored streamwater and rainfall chemistry of mountain watersheds at the Feitsui Reservoir Watershed in northern Taiwan to examine the effects of agriculture on watershed nutrient cycling. We found that the greater the proportion of tea plantation cover, the higher the concentrations of fertilizer-associated ions $\left(\mathrm{NO}_{3}^{-}\right.$, $\mathrm{K}^{+}$) in streamwater of the four mountain watersheds examined; on the other hand, the concentrations of the ions that are rich in soils $\left(\mathrm{SO}_{4}^{2-}, \mathrm{Ca}^{2+}, \mathrm{Mg}^{2+}\right)$ did not increase with the proportion of tea plantation cover, suggesting that agriculture enriched fertilizer-associated nutrients in streamwater. Of the two watersheds for which rainfall chemistry was available, the one with higher proportion of tea plantation cover had higher concentrations of ions in rainfall and retained less nitrogen in proportion to input compared to the more pristine watershed, suggesting that agriculture can influence atmospheric deposition of nutrients and a system's ability to retain nutrients. As expected, we found that a forested watershed downstream of agricultural activities can dilute the concentrations of $\mathrm{NO}_{3}^{-}$in streamwater by more than $70 \%$, indicating that such a landscape configuration helps mitigate nutrient enrichment in aquatic systems even for watersheds with steep topography. We estimated that tea plantation at our study site contributed approximately $450 \mathrm{~kg} \mathrm{ha}^{-1} \mathrm{yr}^{-1}$ of $\mathrm{NO}_{3}-\mathrm{N}$ via streamwater, an order of magnitude greater than previously reported for agricultural lands around the globe, which can only be matched by areas under intense fertilizer use. Furthermore, we constructed watershed $\mathrm{N}$ fluxes to show
\end{abstract}

that excessive leaching of $\mathrm{N}$, and additional loss to the atmosphere via volatilization and denitrification can occur under intense fertilizer use. In summary, this study demonstrated the pervasive impacts of agricultural activities, especially excessive fertilization, on ecosystem nutrient cycling at mountain watersheds.

\section{Introduction}

Agriculture's expansion is taking place in some of the most rugged mountains in the world, including the Hindu Kush Himalaya (Brown and Shrestha, 2000; Tulachan, 2001), in India, China (Johda et al., 1992) and the Andes (Sarmiento and Frolich, 2002). It is well established that watershed nutrient cycling is tightly linked to land use and that conversion of natural forests to agricultural lands causes nutrient enrichment, especially of $\mathrm{N}$ and $\mathrm{P}$, in streamwater (Omernik, 1976; Johnes, 1996; Tilman et al., 2001; Murty et al., 2002; Allan, 2004; Uriarte et al., 2011; Evans et al., 2014). The impacts are likely exacerbated by steep slopes and high precipitation as residence time is reduced and leaching potential increased under such conditions (Brouwer and Powell, 1998; Tokuchi et al., 1999). Thus, mountain agriculture in the tropics and subtropics characterized with high precipitation is likely to have a substantial negative impact on ecosystem function. Yet, empirical studies in tropical or subtropical mountain watersheds are very limited. 
In addition to nutrient output in streamwater, cultivation and fertilization on agricultural lands could affect atmospheric deposition of nutrients (i.e., nutrient input via wet and dry deposition). Fine particles suspended from exposed lands and volatilized gases such as $\mathrm{NH}_{3}$ from manure are scavenged by precipitation (van Breemen et al., 1982), which can then be deposited back to the watersheds. However, in contrast to the large number of reports on streamwater chemistry, few studies of watershed nutrient cycling have examined the effects of land use on precipitation chemistry.

Proper landscape configuration could potentially mitigate the negative effects of agriculture on watershed nutrient cycling. A study at the Hubbard Brook Experimental Forest demonstrated that watershed-level responses were most sensitive to areas of approximately 10-20 ha surrounding the drainage area, where much of the variation in element fluxes occurred (Johnson et al., 2000). Such understanding has led to the common practice of establishing riparian buffer zones as a way to remove pollutants and prevent nutrients from entering streamwater (reviewed by Muscutt et al., 1993). Through proper landscape configuration, negative impacts of agriculture on nutrient cycling in mountain watersheds may also be reduced without sacrificing socioeconomic benefits of agriculture. However, what constitutes a proper landscape configuration is likely to vary with climate and topography.

Here we examined the effects of mountain agriculture, mainly tea plantations, on watershed nutrient cycling at the Feitsui Reservoir Watershed (FRW) in subtropical Taiwan. We first compared streamwater chemistry across four watersheds within the FRW, two with substantial agricultural land use and two primarily covered with natural forests. To assess the effects of agriculture on atmospheric deposition of nutrients and its role in watershed nutrient retention, we focused on the pair of watersheds with the highest and lowest tea plantation covers and compared their rainfall chemistry in relation to streamwater chemistry. The FRW is characterized by high rainfall ( $>3000 \mathrm{~mm}$; Taipei Feitsui Reservoir Administration), steep slopes (on average $42 \%$ ), and heavy use of fertilizers in tea plantations $\left(425-2373 \mathrm{~kg} \mathrm{~N} \mathrm{ha}^{-1} \mathrm{yr}^{-1}\right.$ and 99-551 kg P ha ${ }^{-1} \mathrm{yr}^{-1}$; Water Resources Agency, 2010; see Sect. 2 for details). Many studies have demonstrated substantial nutrient efflux and sediment production from surrounding tea plantations to the reservoir over the past 2 decades (Chang and Wen, 1997; Lu et al., 1999; Kuo and Lee, 2004; Li and Yeh, 2004; Hsieh and Yang, 2006, 2007; Zehetner et al., 2008; Chiueh et al., 2011; Wu and Kuo, 2012). Yet, to our knowledge none examined both the effects of spatial configuration of agricultural lands on nutrient export and the effects of agriculture on atmospheric deposition. The FRW is rare among (sub)tropical mountain watersheds in that the effects of agriculture on its streamwater quality have been intensively studied. With the addition of this study, we believe that the FRW can serve as a classic case illustrating the effects of agriculture on nutrient cycling in watersheds with rugged topography and high precipitation, which can be very informative to other less-studied (sub)tropical mountain watersheds.

We hypothesized that agriculture would increase nutrient output in streamwater $\left(H_{1}\right)$ as well as atmospheric input of nutrients through rainfall $\left(\mathrm{H}_{2}\right)$. We also hypothesized that through the disruption of natural vegetation, agriculture would increase nutrient leaching and decrease the retention ratio of essential nutrient elements $\left(\mathrm{H}_{3}\right)$. Our specific predictions are that

- watersheds with higher proportion of tea plantation cover have higher concentrations and fluxes of fertilizerassociated ions in the streamwater than forested watersheds $\left(H_{1}\right)$,

- watersheds with higher proportion of tea plantation cover have higher concentrations and fluxes of fertilizerassociated ions in the rainfall than forested watersheds $\left(H_{2}\right)$,

- watersheds with higher proportion of tea plantation cover have a lower nitrogen retention ratio (in proportion to input) than forested watersheds $\left(\mathrm{H}_{3}\right)$.

In addition, we explored (1) the role of landscape configuration in mitigating agricultural effects by quantifying the dilution effects of a forested watershed downstream from watersheds with substantial tea plantation cover, and (2) the $\mathrm{N}$ and $\mathrm{P}$ dynamics associated with tea plantations by quantifying the differences in their fluxes between a forested watershed (background values) and a nearby watershed with substantial tea plantation cover.

\section{Materials and methods}

\subsection{Study site}

The FRW is located along the Peishi Creek of northern Taiwan, with a drainage area of $303 \mathrm{~km}^{2}$. The elevation of the FRW ranges from 45 to $1127 \mathrm{~m}$, with a mean slope of $42 \%$ (Fig. 1). The underlying geology of the FRW region is mainly argillite and slate with sandstone interbeds, and the soils are mostly Entisols and Inceptisols with high silt contents (Zehetner et al., 2008).

Annual precipitation is high and spatially varied, ranging from $3500 \mathrm{~mm}$ in the southwest portion of the FRW to $5100 \mathrm{~mm}$ in the northwest during 2001-2010 (J. C. Huang, unpublished data). The vegetation is primarily composed of secondary-growth, mixed broad-leaf forests dominated by Fagaceae and Lauraceae (Chen, 1993). Approximately $16 \%$ of the FRW is agricultural land with tea plantations covering an area of 1200 ha, or $25 \%$ of all agricultural lands (Chang and Wen, 1997; Chou et al., 2007). In 1986 the FRW was designated as a water resource protection area, followed by the construction of the Feitsui Reservoir in 1987. Today, the reservoir provides drinking water to the six million people 


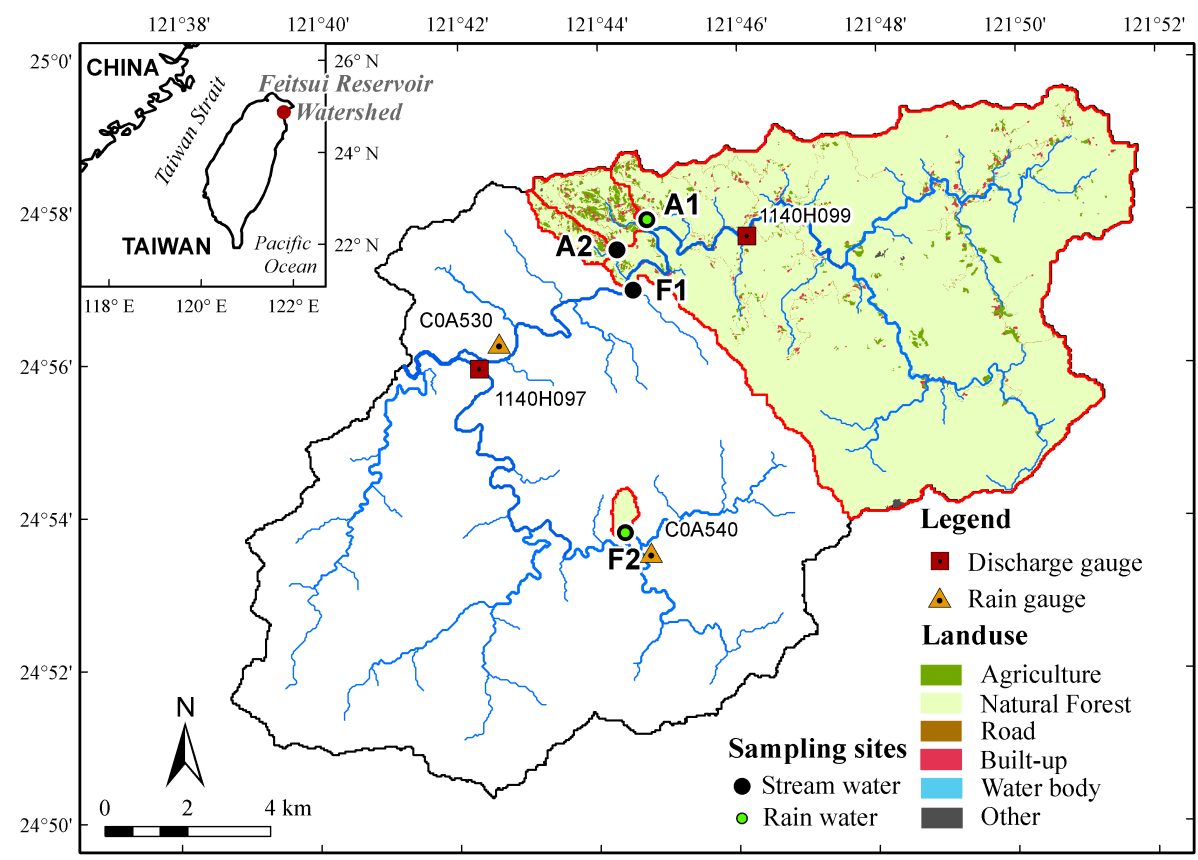

Figure 1. Location and land use distribution of the studied watersheds.

in the Taipei metropolitan area. The forests in the FRW have been protected (no cutting, thinning or converting to agricultural use) since 1986. Therefore, current agricultural activities are limited to private lands with a pre-existing agricultural use which still has an impact at the study site.

\subsection{Sampling regime}

Four watersheds of the FRW (A1, A2, F1, F2; Fig. 1) with varying proportions of tea plantation cover $(22 \%$ in $\mathrm{A} 1,17 \%$ in $\mathrm{A} 2,2.9 \%$ in $\mathrm{F} 1,0.4 \%$ in F2; Table 1) were included in this study. Other crops make up only a small proportions of the watersheds $(<1 \%)$, so they are not included in Table 1 . Natural forests are the most dominant land cover for all four watersheds $(68 \%$ in $\mathrm{A} 1,76 \%$ in $\mathrm{A} 2,93 \%$ in $\mathrm{F} 1,99 \%$ in F2; Table 1), making tea plantation the primary contributor to the differences in landscape across the four watersheds. Weekly samples of streamwater were collected from all four watersheds. In addition, weekly samples of rainwater were collected from the two watersheds with the lowest (F2) and highest proportions of agricultural lands (A1). A1, A2, and F2 are watersheds $\left(<3 \mathrm{~km}^{2}\right)$ drained by first-order streams whereas F1 is a much larger watershed $\left(86 \mathrm{~km}^{2}\right)$ drained by a third order stream that drains through A1 and A2 (Fig. 1). We collected weekly rainfall and streamwater samples every Tuesday from September 2012 to August 2014. Rainfall samples were collected using a $20 \mathrm{~cm}$ diameter polyethylene (PE) bucket, from which a $600 \mathrm{~mL}$ subsample was taken and placed into a PE bottle for transportation back to the laboratory. Streamwater samples were collected by dipping a PE bucket into the stream and, similarly to rainfall sampling, a
Table 1. Basic information of the studied watersheds.

\begin{tabular}{lcccc}
\hline & A1 & A2 & F1 & F2 \\
\hline Area $\left(\mathrm{km}^{2}\right)$ & 2.92 & 1.36 & 86.04 & 0.67 \\
Slope (\%) & 39.3 & 34.8 & 38.7 & 48.1 \\
\hline \multicolumn{5}{c}{ Land use (\%) } \\
Natural forest & 68.0 & 75.5 & 93.5 & 99.2 \\
Agriculture & 22.1 & 17.1 & 2.87 & 0.38 \\
Road & 3.61 & 2.96 & 0.77 & 0.00 \\
Building & 1.54 & 1.31 & 0.35 & 0.00 \\
Water body & 0.69 & 0.19 & 1.12 & 0.00 \\
Others & 4.11 & 2.96 & 1.44 & 0.38 \\
\hline
\end{tabular}

$600 \mathrm{~mL}$ subsample was taken and placed into a PE bottle for transportation back to the laboratory.

\subsection{Water chemistry}

All samples were transported back to the laboratory within $24 \mathrm{~h}$. Conductivity and $\mathrm{pH}$ of the water samples were measured on the same day of collection. The samples were filtered through $0.45 \mu \mathrm{m}$ filter paper. Major cations $\mathrm{Na}^{+}, \mathrm{K}^{+}$, $\left.\mathrm{Ca}^{2+}, \mathrm{Mg}^{2+}, \mathrm{NH}_{4}^{+}\right)$and anions $\left(\mathrm{Cl}^{-}, \mathrm{SO}_{4}^{2-}, \mathrm{NO}_{3}^{-}\right)$were analyzed by ion chromatography on filtered samples using Dionex ICS 1000 and DX 120 (Thermo Fisher Scientific Inc. Sunnyvale, CA, USA). $\mathrm{PO}_{4}^{3-}$ was measured using standard vitamin-C molybdenum-blue method with the detection limit of $0.01 \mu \mathrm{M}$ (APHA, 2005). Prior to chemical analysis, samples were stored at $4{ }^{\circ} \mathrm{C}$ without preservatives. 
Data on rainfall and streamflow quantity of the watersheds were estimated from the rain gauges and discharge gauges maintained by the Central Weather Bureau and Water Resource Agency of Taiwan, respectively. The distance between a watershed and its nearest rain gauges was $1.0-8.5 \mathrm{~km}$, and that between a watershed and its nearest discharge gauges was $3.0-5.0 \mathrm{~km}$. The weekly and monthly rainfall of a watershed was directly assigned to the values registered at the nearest rain gauge (i.e., COA530 for A1 and COA540 for F2; Fig. 1, S1a). The weekly and monthly streamflow of a watershed was estimated by the area ratio method in which the streamflow was assigned to the values registered at the nearest discharge gauge (i.e., $1140 \mathrm{H} 099$ for A1, A2, and F1, and $1140 \mathrm{H} 097$ for F2; Fig. S1b) and then adjusted by the area ratio of the studied watershed relative to the watershed where the discharge gauge was located. The validity of this method has been confirmed for several watersheds in Taiwan (Huang et al., 2012; Lee et al., 2014).

\subsection{Element fluxes}

Weekly element fluxes through rainfall and streamflow of A1 and F2 were derived by multiplying weekly concentrations by weekly rainfall/streamflow. Monthly fluxes were accumulated from weekly fluxes, and when a weekly sample spanned over 2 months, it was divided into the 2 months in proportion to the rainfall/streamflow quantity.

In order to provide a more comprehensive understanding on how mountain agriculture affects watershed nutrient cycling, we constructed and compared $\mathrm{N}$ and $\mathrm{P}$ fluxes for watersheds with the highest (A1) and lowest (F2) tea plantation cover. We made three assumptions in the calculation of watershed nutrient fluxes. First, we assumed the input from dry deposition is $28 \%$ of that from precipitation for both watersheds. This value was based on a study using the $\mathrm{Na}^{+}$ratio method at the Fushan Experimental Forest (Lin et al., 2000), a natural hardwood forest $17 \mathrm{~km}$ south of the FRW. Second, the amount of fertilizer used is assumed to be close to $786 \mathrm{~kg} \mathrm{Nha}^{-1} \mathrm{yr}^{-1}$ and $171 \mathrm{~kg} \mathrm{Pha}^{-1} \mathrm{yr}^{-1}$, the values taken from a case study in which the management practices (e.g., applications of fertilizers and pesticides, time and yield of harvests) were carefully recorded by a farmer in the same region as the current study (Tsai and Tsai, 2008). Although only one farmer was involved in the case study, the values are consistent with those reported by FAO (2002) and very close to the mean values across 10 tea plantations in our study area $\left(743 \mathrm{~kg} \mathrm{Nha}^{-1} \mathrm{yr}^{-1}\right.$ ranging from 425 to $2373 \mathrm{~kg} \mathrm{Nha}^{-1} \mathrm{yr}^{-1}$, and $179 \mathrm{~kg} \mathrm{Pha}^{-1} \mathrm{yr}^{-1}$ ranging from 99 to $550 \mathrm{~kg} \mathrm{Pha}^{-1} \mathrm{yr}^{-1}$; Water Resources Agency, 2010). Adjusting for the proportion of agricultural lands (22.1, $0.38 \%$ ), the amounts of fertilizers used in A1 were estimated to be $173.7 \mathrm{~kg} \mathrm{Nha}^{-1} \mathrm{yr}^{-1}$ and $37.8 \mathrm{~kg} \mathrm{Pha}^{-1} \mathrm{yr}^{-1}$, and those in $\mathrm{F} 2$ to be $3 \mathrm{~kg} \mathrm{Nha}^{-1} \mathrm{yr}^{-1}$ and $0.6 \mathrm{~kg} \mathrm{Pha}^{-1} \mathrm{yr}^{-1}$. There was very little change in biomass of tea plantation after 10 years because tea plants are regularly trimmed, with the litter left in the field, to maintain the same height optimal for harvest. Thus, our third assumption is that $\mathrm{N}$ and $\mathrm{P}$ is lost due to the uptake by tea trees being equivalent to the $\mathrm{N}$ and $\mathrm{P}$ in the harvested tea leaves. The amount of $\mathrm{N}$ removed through tea harvest $\left(113 \mathrm{~kg} \mathrm{ha}^{-1} \mathrm{yr}^{-1}\right)$ was taken from the same case study and the amount of $\mathrm{P}$ removed $\left(7.35 \mathrm{~kg} \mathrm{ha}^{-1} \mathrm{yr}^{-1}\right)$ was calculated using the median of $\mathrm{P}: \mathrm{N}$ ratios $(0.065)$ reported for tea trees in Taiwan (Tsai and Tsai, 2008). After adjusting for the proportion of tea plantation cover, A1 was estimated to have $25.0 \mathrm{~kg} \mathrm{~N}^{-1} \mathrm{yr}^{-1}$ and $1.6 \mathrm{~kg} \mathrm{Pha}^{-1} \mathrm{yr}^{-1} \mathrm{re}-$ moved through harvest, and $\mathrm{F} 2$ to have $0.43 \mathrm{~kg} \mathrm{Nha}^{-1} \mathrm{yr}^{-1}$ and $0.03 \mathrm{~kg} \mathrm{Pha}^{-1} \mathrm{yr}^{-1}$ removed through harvest. Using the following mass balance model, we constructed fluxes of $\mathrm{N}$ and $\mathrm{P}$ of the two watersheds:

Ratio $_{\text {ret }}=1-\frac{\text { OUT }_{\text {riv }}+\text { OUT }_{\text {harv }}}{\mathrm{IN}_{\mathrm{dep}}+\mathrm{IN}_{\mathrm{fer}}+\mathrm{IN}_{\mathrm{fix}}}$.

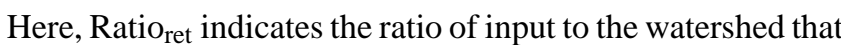
was retained within the watershed. The OUT $\mathrm{T}_{\text {riv }}$ and OUT are the riverine export and harvest, respectively. The $\mathrm{IN}_{\mathrm{dep}}$, $\mathrm{IN}_{\mathrm{fer}}$, and $\mathrm{IN}_{\mathrm{fix}}$ indicate the atmospheric deposition, fertilizer application, and biological fixation. Note that the biologic fixation term was not used for P calculation. Since the tea plantation does not use leguminous crop as fertilizers and the biological fixation in tropical forest is known to be less than $10 \mathrm{~kg} \mathrm{Nha}^{-1} \mathrm{yr}^{-1}$ (Sullivan et al., 2014), the $\mathrm{IN}_{\mathrm{fix}}$ is assumed to be between 0 and $10 \mathrm{~kg} \mathrm{Nha}^{-1} \mathrm{yr}^{-1}$. We did not include the loss through denitrification and volatilization within tea field in the calculation of $\mathrm{N}$ retention ratio because we did not have good estimates. However, the effects of such uncertainties and omissions on estimating $\mathrm{N}$ retention ratio were discussed. We did not calculate the retention ratio for $\mathrm{P}$ because the majority of $\mathrm{P}$ in watersheds was in particulate forms (Smith et al., 1991) that were not analyzed in our study.

\subsection{Statistical analysis}

We used the general linear model with repeated measurements to compare monthly concentration and flux of ions in streamwater among the four watersheds (F1, F2, A1, A2), followed by Fisher's least significant difference (LSD) post hoc comparisons. $\mathrm{NH}_{4}^{+}$was excluded from streamwater analysis due to its low concentration. We used a onetail paired $t$ test to examine if monthly ion concentration (volume weighted from weekly samples) and flux in rainfall were higher at the watershed with higher agricultural land cover (A1) than the more pristine watershed (F2). All statistical analysis was conducted using SPSS 22.0 (IBM Corporation, New York). 


\section{Results}

\subsection{Streamwater chemistry}

The concentrations of all analyzed ions in streamwater differed significantly among the four watersheds (Table 2). A1, the watershed with the highest proportion covered by tea plantations, had significantly higher concentrations of all ions except $\mathrm{H}^{+}$than the other three watersheds (Table 2, Fig. 2). In contrast, F2, the watershed with the lowest proportion covered by tea plantations, had the lowest concentrations of $\mathrm{H}^{+}, \mathrm{Na}^{+}, \mathrm{K}^{+}, \mathrm{Cl}^{-}$, and $\mathrm{NO}_{3}^{-}$. Furthermore, it is worth noting that $\mathrm{F} 2$, the watershed with the steepest slopes, had the second highest concentrations of ions rich in soils and soil solution, including $\mathrm{Ca}^{2+}, \mathrm{Mg}^{2+}$, and $\mathrm{SO}_{4}^{2-}$ (Table 2, Fig. 2).

Similar to ion concentration, the fluxes of all ions differed significantly among watersheds (Table 2). A1 had the largest fluxes of $\mathrm{K}^{+}, \mathrm{Ca}^{2+}, \mathrm{Mg}^{2+}, \mathrm{NO}_{3}^{-}$, and $\mathrm{SO}_{4}^{2-}$ and $\mathrm{F} 2$ had the smallest fluxes of $\mathrm{H}^{+}, \mathrm{Na}^{+}, \mathrm{K}^{+}, \mathrm{Mg}^{2+}, \mathrm{Cl}^{-}$, and $\mathrm{NO}_{3}^{-}$ (Table 2). $\mathrm{PO}_{4}^{3-}$ flux was significantly larger at $\mathrm{A} 1$ and $\mathrm{A} 2$, which were not so different from each other, than F1 and F2, which were also not so different from each other (Table 2). Although the fluxes of $\mathrm{Na}^{+}$and $\mathrm{Cl}^{-}$differed significantly among $\mathrm{A} 1, \mathrm{~A} 2$, and $\mathrm{F} 1$, these differences were considerably smaller than the differences between the three watersheds and F2 (Table 2).

\subsection{Rainfall chemistry}

Five of the 10 measured ions had significant $(p<0.05)$ or marginally significant $(p<0.1)$ higher concentrations in A1 than in $\mathrm{F} 2\left(\mathrm{H}^{+}, \mathrm{Na}^{+}, \mathrm{Cl}^{-}, \mathrm{NO}_{3}^{-}, p<0.05 ; \mathrm{NH}_{4}^{+}, p=0.067\right.$; Table 3, Fig. 3). Furthermore, 7 of the 10 measured ions had significant or marginally significant higher fluxes in $\mathrm{A} 1$ than in $\mathrm{F} 2\left(\mathrm{H}^{+}, \mathrm{Ca}^{2+}, \mathrm{Cl}^{-}, p<0.05 ; \mathrm{Na}^{+}, \mathrm{Mg}^{2+}, \mathrm{NH}_{4}^{+}, \mathrm{NO}_{3}^{-}\right.$, $p<0.1$; Table 3 ).

\section{3 $\mathrm{N}$ and $\mathrm{P}$ fluxes}

Because the proportion of agricultural cover was very low at F2 (i.e., $0.38 \%$ ) and the resulting fertilizer input and harvest output were small and already accounted for (Table 4), we treated $\mathrm{F} 2$ as a background and attributed the differences between $\mathrm{A} 1$ and $\mathrm{F} 2$ to agricultural activities. We estimated stream $\mathrm{N}$ and $\mathrm{P}$ outputs from the tea plantation at $\mathrm{A} 1$ to be approximately 105.7 and $1.6 \mathrm{~kg} \mathrm{ha}^{-1} \mathrm{yr}^{-1}$, respectively (Table 4). Scaling up from $22 \%$ of tea plantation cover to $100 \%$, the stream $\mathrm{N}$ and $\mathrm{P}$ outputs from $\mathrm{A} 1$ could reach as high as 450 and $7.3 \mathrm{~kg} \mathrm{ha}^{-1} \mathrm{yr}^{-1}$, respectively.

From our mass balance construction of element fluxes, $\mathrm{N}$ input exceeded output at both watersheds (Table 4, Fig. 4). At $\mathrm{A} 1,35 \%$ of the $\mathrm{N}$ input $\left(69 \mathrm{~kg} \mathrm{ha}^{-1} \mathrm{yr}^{-1}\right)$ to the watershed was retained (Table 4, Fig. 4). At F2, $72 \%$ of the $\mathrm{N}$ input (15 $\mathrm{kg} \mathrm{Nha}^{-1} \mathrm{yr}^{-1}$ ) was retained (Table 4, Fig. 4).
For $\mathrm{P}$, the output through streamflow $\left(2.6 \mathrm{~kg} \mathrm{ha}^{-1} \mathrm{yr}^{-1}\right)$ was smaller than the input through atmospheric deposition (3.6 $\mathrm{kg} \mathrm{ha}^{-1} \mathrm{yr}^{-1}$ ) at F2. At A1, the output of P through streamflow and harvest $\left(5.8 \mathrm{~kg} \mathrm{ha}^{-1} \mathrm{yr}^{-1}\right)$ was greater than the input through atmospheric deposition $\left(4.6 \mathrm{~kg} \mathrm{ha}^{-1} \mathrm{yr}^{-1}\right)$, but when fertilization was taken into account, the total output of $\mathrm{PO}_{4}^{3-}-\mathrm{P}$ was trivial relative to the total $\mathrm{P}$ input (42.4 $\mathrm{kg} \mathrm{ha}^{-1} \mathrm{yr}^{-1}$ ) (Table 4).

\section{Discussion}

\subsection{Streamwater chemistry}

The watershed with the highest proportion of tea plantation cover (A1) had the highest concentrations and fluxes of most ions in streamwater, suggesting the role of agriculture on increasing nutrient output. Furthermore, the fact that the output of fertilizer-associated ions $\left(\mathrm{NO}_{3}^{-}\right.$and $\left.\mathrm{K}^{+}\right)$matched the proportion of tea plantation cover across the four watersheds (i.e., the rank of the proportion of tea plantation cover from high to low: A1, A2, F1, and F2; rank of ion concentration and flux from high to low: A1, A2, F1, and F2) strongly supports the effects of agriculture on streamwater chemistry $\left(H_{1}\right)$.

However, streamwater chemistry is affected by complex processes beyond a single factor of land use. For example, $\mathrm{P}$ is also an important component of fertilizers but, unlike $\mathrm{NO}_{3}^{-}$and $\mathrm{K}^{+}$, the concentration of $\mathrm{PO}_{4}^{3-}$ at $\mathrm{F} 2$ was not significantly different from that at $\mathrm{A} 1$ and $\mathrm{A} 2$, and all were significantly higher than F1. Erosion is known to enhance leaching loss of $\mathrm{PO}_{4}^{3-}$ (Gaynor and Findlay, 1995; Turtola and Jaakkola, 1995; Liu et al., 2006; Chang et al., 2008; Lee et al., 2013). The greater erosion and leaching associated with the steeper slopes of F2 may have matched the effect of fertilization and led $\mathrm{F} 2$ to have a $\mathrm{PO}_{4}^{3-}$ concentration as high as $\mathrm{A} 1$ and A2. To further illustrate this topographic effect, we compared streamwater chemistry between the two forested watersheds (F1 and F2), removing the potential confounding effect of land use. Indeed, the steeper F2 (48\%) had a higher $\mathrm{PO}_{4}^{3-}$ concentration than the less steep F1 (39\%) (Fig. 2, Table 2), despite that F2 has a higher proportion of natural forest cover. Soil erosion is arguably the greatest concern to most $\mathrm{P}$ mitigation programs because the concentration of $\mathrm{P}$ on the surface of soil particles is often orders of magnitude greater than that in a soil solution (Sharpley et al., 2002; Kleinman et al., 2011). Therefore, it is not surprising that topography may be a more important driver for riverine $\mathrm{P}$ than land use at our study site. The enhanced erosion/leaching associated with the steeper slope at F2 may also explain why $\mathrm{F} 2$ had the second highest concentration of $\mathrm{SO}_{4}^{2-}, \mathrm{Ca}^{2+}$, and $\mathrm{Mg}^{2+}$, the ions that are abundant in soils. 
$\mathrm{H}^{+}$

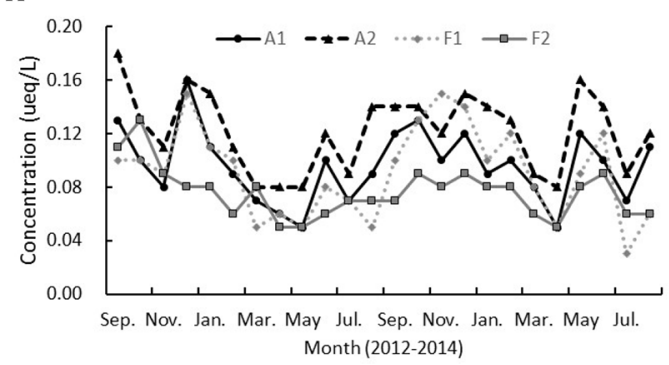

$\mathrm{K}^{+}$

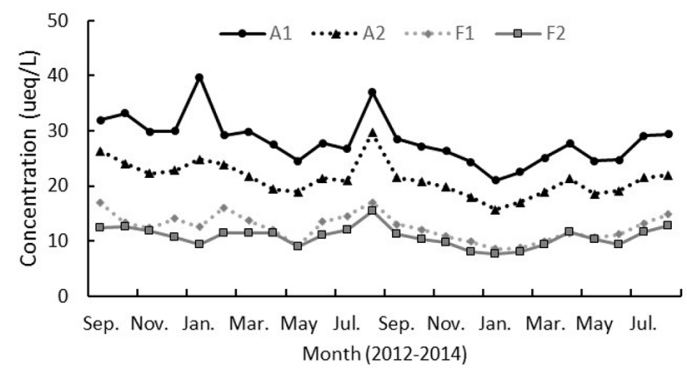

$\mathrm{Mg}^{2+}$

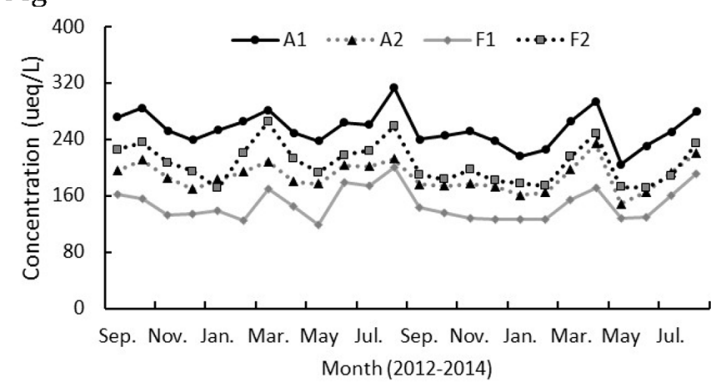

$\mathrm{NO}_{3} \cdot$

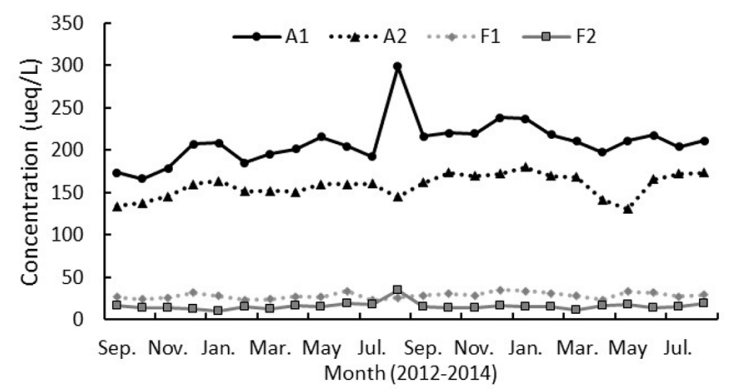

$\mathrm{PO}_{4}^{3-}$

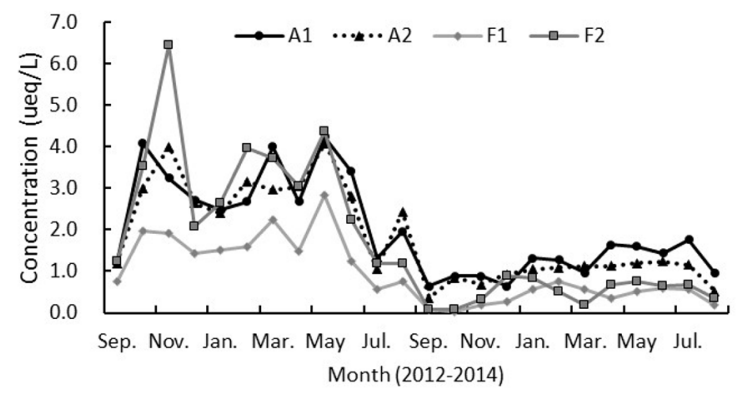

$\mathrm{Na}^{+}$

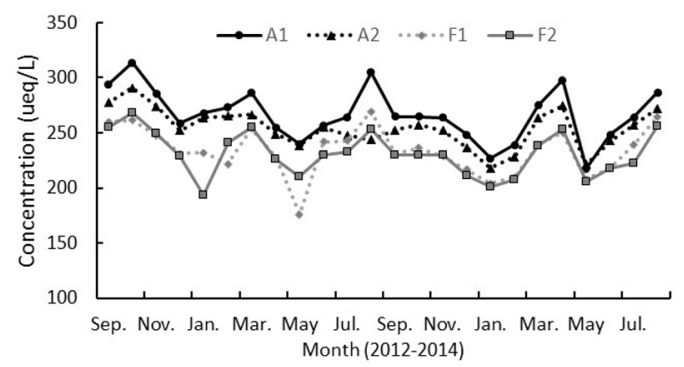

$\mathrm{Ca}^{2+}$

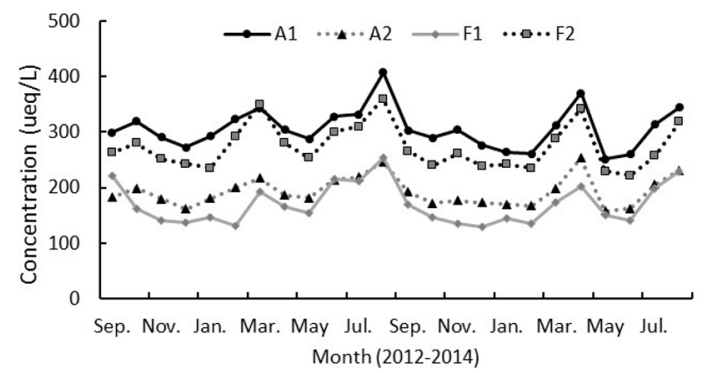

$\mathrm{Cl}^{-}$

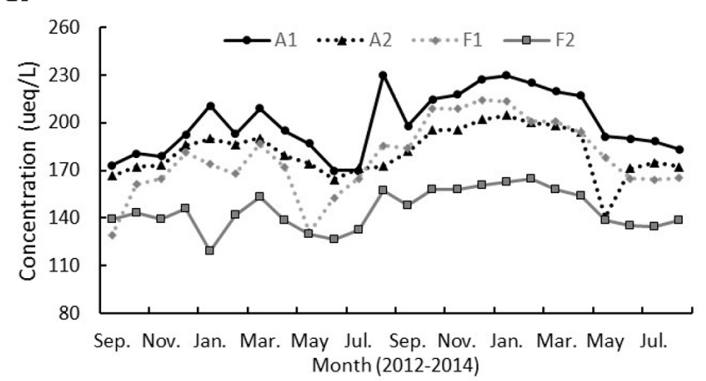

$\mathrm{SO}_{4}^{2-}$

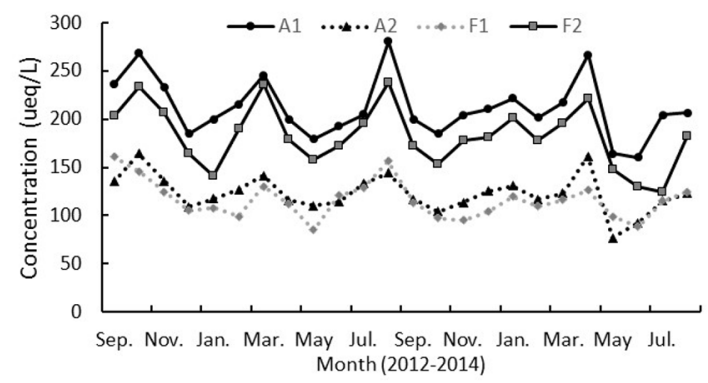

Figure 2. Monthly ion concentration (volume-weighted from weekly samples) of streamwater of watersheds A1, A2, F1, and F2. 
$\mathrm{H}^{+}$

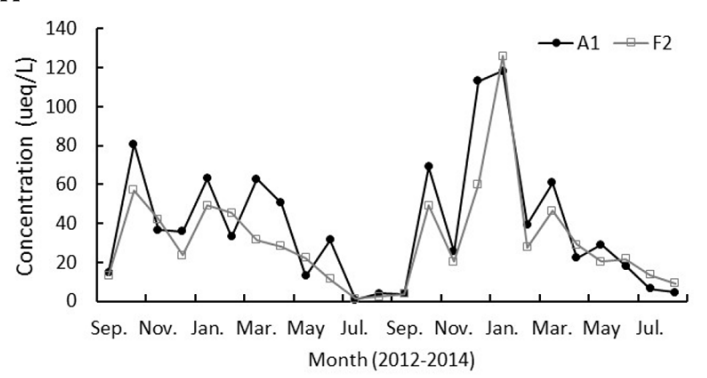

$\mathrm{K}^{+}$

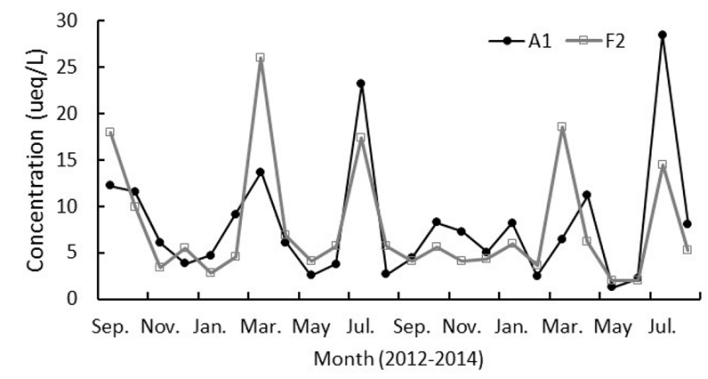

$\mathrm{Mg}^{2+}$

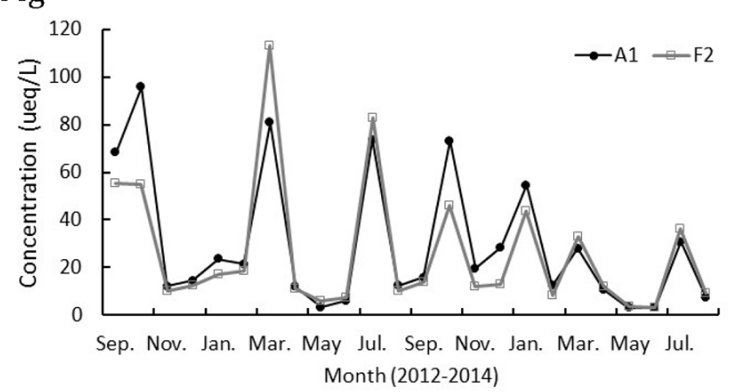

$\mathrm{Cl}^{-}$

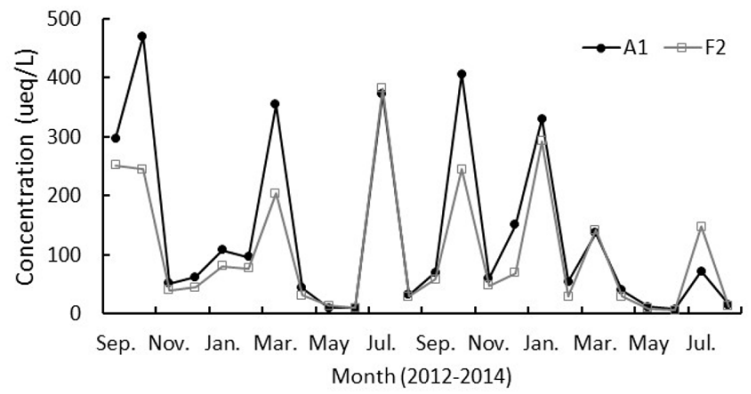

$\mathrm{SO}_{4}{ }^{2-}$

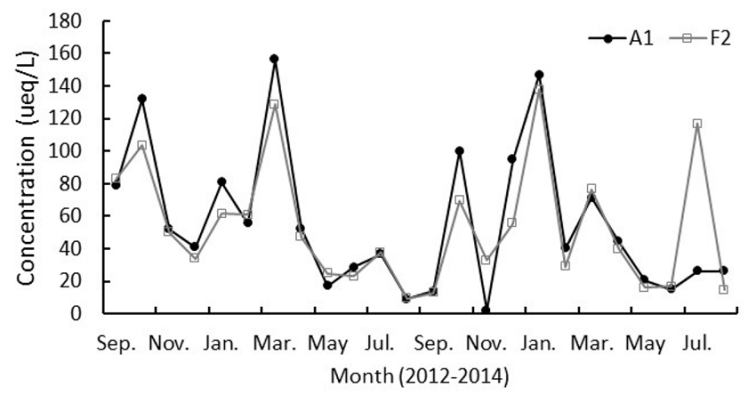

$\mathrm{Na}^{+}$

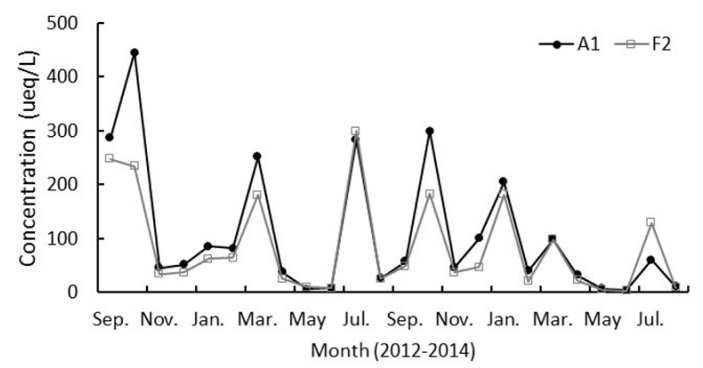

$\mathrm{Ca}^{2+}$

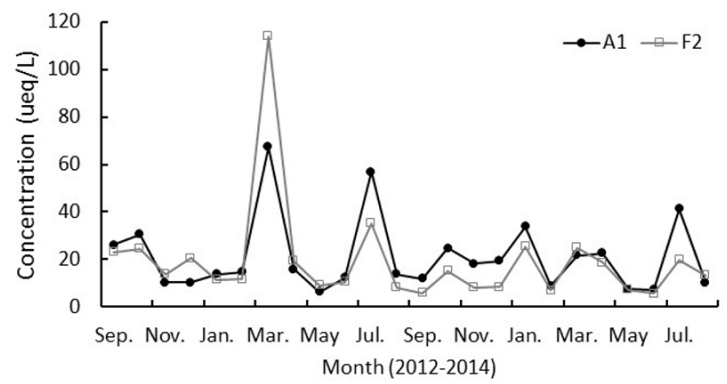

$\mathrm{NH}_{4}{ }^{+}$

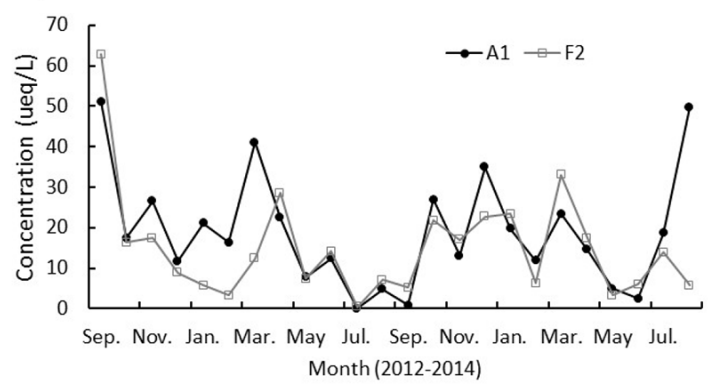

$\mathrm{NO}_{3} \cdot$

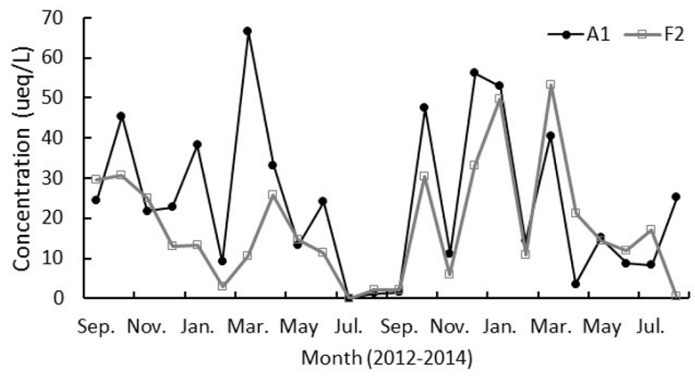

Figure 3. Monthly ion concentration (volume-weighted from weekly samples) of rainfall of watersheds A1 and F2. 


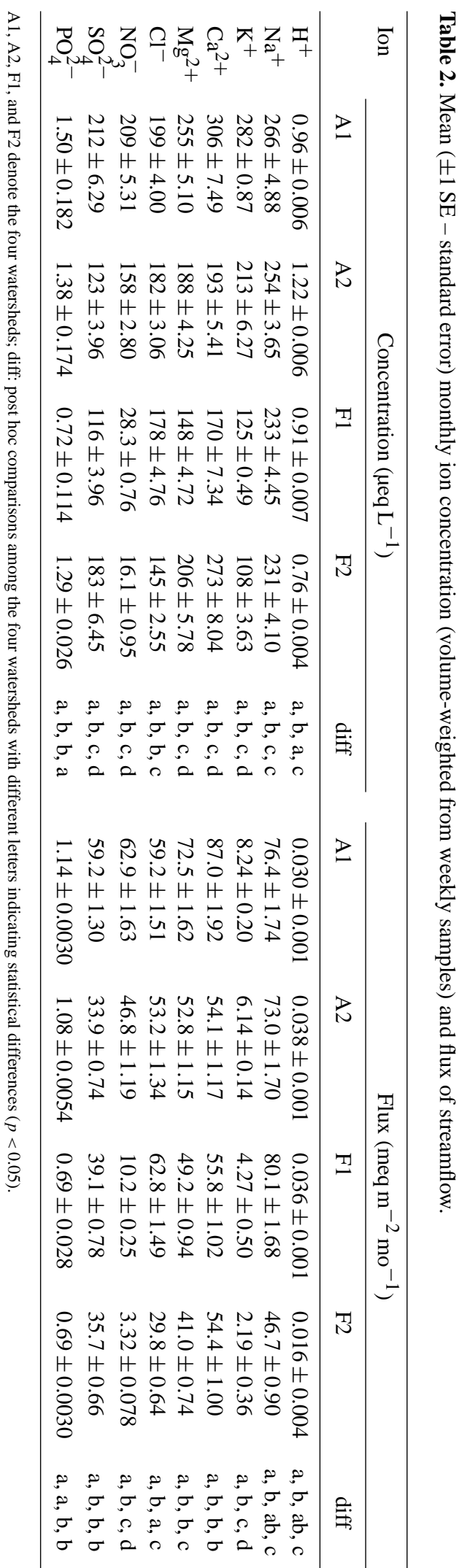

Table 3. Mean ( $\pm 1 \mathrm{SE})$ monthly ion concentration (volumeweighted from weekly samples) and flux of rainfall.

\begin{tabular}{llllll}
\hline \multirow{2}{*}{ Ion } & \multicolumn{2}{c}{ Concentration $\left(\mu \mathrm{eq} \mathrm{L}^{-1}\right)$} & & \multicolumn{2}{c}{ Flux $\left(\mathrm{meq} \mathrm{m}^{-2} \mathrm{mo}^{-1}\right)$} \\
\cline { 2 - 3 } \cline { 5 - 6 } & A1 & F2 & & A1 & F2 \\
\hline $\mathrm{H}^{+}$ & $39 \pm 6.7$ & $31 \pm 5.4^{*}$ & & $12 \pm 3.9$ & $7.9 \pm 1.5^{*}$ \\
$\mathrm{Na}^{+}$ & $107 \pm 24$ & $84 \pm 18^{*}$ & & $30 \pm 8.5$ & $23 \pm 6 .\left(^{*}\right)$ \\
$\mathrm{K}^{+}$ & $8.0 \pm 1.3$ & $7.8 \pm 1.3$ & & $2.2 \pm 0.45$ & $1.9 \pm 0.32$ \\
$\mathrm{Ca}^{2+}$ & $21 \pm 3.2$ & $19 \pm 4.4$ & & $5.7 \pm 1.0$ & $4.2 \pm 0.61^{*}$ \\
$\mathrm{Mg}^{2+}$ & $30 \pm 5.8$ & $26 \pm 5.6$ & & $8.2 \pm 2.1$ & $6.5 \pm 1.7\left(^{*}\right)$ \\
$\mathrm{NH}_{4}^{+}$ & $19 \pm 2.9$ & $15 \pm 2.7\left(^{*}\right)$ & & $5.1 \pm 1.3$ & $3.8 \pm 0.67\left(^{*}\right)$ \\
$\mathrm{Cl}^{-}$ & $140 \pm 30$ & $100 \pm 22^{*}$ & & $38 \pm 11$ & $28 \pm 8.2^{*}$ \\
$\mathrm{NO}_{3}^{-}$ & $24 \pm 3.9$ & $18 \pm 3.0^{*}$ & & $7.0 \pm 2.0$ & $4.7 \pm 0.90\left(^{*}\right)$ \\
$\mathrm{SO}_{4}^{2-}$ & $58 \pm 8.6$ & $53 \pm 7.7$ & & $15 \pm 3.6$ & $13 \pm 2.4$ \\
$\mathrm{PO}_{4}^{3-}$ & $0.96 \pm 0.03$ & $0.63 \pm 0.03$ & & $0.75 \pm 0.30$ & $0.51 \pm 0.12$ \\
\hline $\mathrm{Al}^{3}$ & & & & &
\end{tabular}

A1 and F2 denote the two watersheds; an asterisk ${ }^{*}$ indicates a significant difference between the two watershed $(p<0.05)$; an asterisk inside a parenthesis $(*)$ indicates a marginally significant difference between the two watersheds $(p<0.1)$.

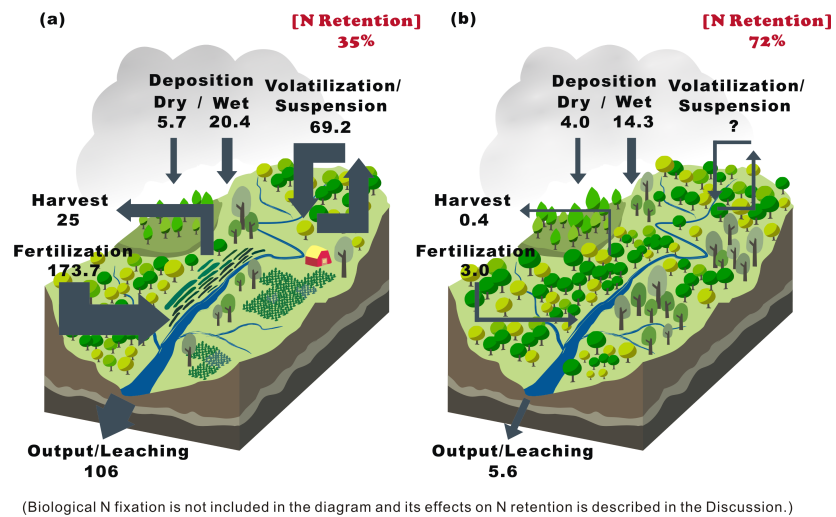

Figure 4. Schematic diagram of $\mathrm{N}$ fluxes of watersheds $\mathrm{A} 1$ and $\mathrm{F} 2$. A1 represents a watershed with $22 \%$ agricultural lands and $68 \%$ forests (a); F2 represents a watershed with $0.38 \%$ agricultural lands and $99 \%$ forests (b) (unit: $\mathrm{kg} \mathrm{Nha}^{-1} \mathrm{yr}^{-1}$ ).

\subsection{Rainfall chemistry}

We confirmed that agricultural activities can influence watershed nutrient cycling via atmospheric deposition in our study site $\left(\mathrm{H}_{2}\right)$. We found higher concentrations and fluxes of $\mathrm{NO}_{3}^{-}$ and $\mathrm{NH}_{4}^{+}$in rainfall at $\mathrm{A} 1$, a watershed with $22 \%$ of tea plantation cover, compared to F2, the watershed almost entirely covered by natural forests. Ammonium sulfate, urea and calcium ammonium nitrate $\left[5 \mathrm{Ca}\left(\mathrm{NO}_{3}\right)_{2} \cdot \mathrm{NH}_{4} \mathrm{NO}_{3} \cdot 10 \mathrm{H}_{2} \mathrm{O}\right]$, which contain a high quantity of $\mathrm{NO}_{3}^{-}$and $\mathrm{NH}_{4}^{+}$are commonly used $\mathrm{N}$ fertilizers in Taiwan (Huang, 1994). Therefore, in tea plantations at FRW, substantial suspension and volatilization of ammonium sulfate, urea, and calcium ammonium nitrate likely contributed to the high concentrations and fluxes of $\mathrm{NO}_{3}^{-}$and $\mathrm{NH}_{4}^{+}$in rainfall at $\mathrm{A} 1$. On the other hand, the concentrations of $\mathrm{PO}_{4}^{3-}$ and $\mathrm{K}^{+}$in rainfall were not higher at $\mathrm{A} 1$ compared to $\mathrm{F} 2$, which may be explained 
Table 4. Inputs and outputs of nitrogen and phosphorus of watersheds A1 and F2. See text for the assumptions made in the calculations of dry deposition, fertilization, and harvest.

\begin{tabular}{|c|c|c|c|c|}
\hline & \multicolumn{2}{|c|}{$\begin{array}{c}\text { Nitrogen } \\
\left(\mathrm{kg} \mathrm{ha}^{-1} \mathrm{yr}^{-1}\right)\end{array}$} & \multicolumn{2}{|c|}{$\begin{array}{c}\text { Phosphorus } \\
\left(\mathrm{kg} \mathrm{ha}^{-1} \mathrm{yr}^{-1}\right)\end{array}$} \\
\hline & A1 & $\mathrm{F} 2$ & A1 & $\mathrm{F} 2$ \\
\hline \multicolumn{5}{|c|}{ Input } \\
\hline Wet deposition & 20.4 & 14.3 & 3.6 & 2.8 \\
\hline Dry deposition & 5.7 & 4.0 & 1.0 & 0.8 \\
\hline Fertilization & 173.7 & 3.0 & 37.8 & 0.6 \\
\hline Total & 199.8 & 21.3 & 42.4 & 4.2 \\
\hline \multicolumn{5}{|c|}{ Output } \\
\hline Harvest & 25.0 & 0.4 & 1.6 & 0.0 \\
\hline Stream output* & 105.7 & 5.6 & 4.2 & 2.6 \\
\hline Total & 130.7 & 6.0 & 5.8 & 2.6 \\
\hline
\end{tabular}

* For stream output, only dissolved inorganic forms are considered.

by the low mobility of $\mathrm{PO}_{4}^{3-}$ and smaller quantity of $\mathrm{P}$ and $\mathrm{K}$ in fertilizers.

Once in the atmosphere, aerosols/chemicals can be transported to other locations but most of them will be deposited in nearby ecosystems. In central Taiwan, the high $\mathrm{NH}_{4}^{+}$concentration in precipitation in a high elevation forest $(2000 \mathrm{~m})$ was attributed to mountain agriculture that occurred $10 \mathrm{~km}$ away (Ding et al., 2011). With the predicted expansion of agriculture to the mountains both in Taiwan and many other regions (Johda et al., 1992; Brown and Shrestha, 2000; Tulachan, 2001), even pristine ecosystems will not be free from the impacts (e.g., acidification and eutrophication associated with $\mathrm{H}^{+}$and $\mathrm{NO}_{3}^{-}$) of agricultural activities.

Because Taiwan is a small island, sea salt aerosols are important components of rainfall (Lin et al., 2000). The distance to the coast, specifically, has been used to explain the variation of $\mathrm{Na}^{+}$and $\mathrm{Cl}^{-}$concentrations in precipitation among four sites in central Taiwan (Ding et al., 2011). The higher concentrations and fluxes of $\mathrm{Na}^{+}$and $\mathrm{Cl}^{-}$, and to a lesser degree $\mathrm{Mg}^{2+}$, at $\mathrm{A} 1$ than at F2 likely reflected such oceanic influences. The watersheds receive winter rains, along with sea salt aerosols, from the north/northeast coasts (northeast monsoon). While A1 is located on the windward side, F2 is on the leeward side. Therefore, a substantial proportion of the sea salt aerosols may have been intercepted before they can reach F2. Although summer rains move from the opposite direction, the watersheds are relatively far from the west/southwest coasts $(>60 \mathrm{~km})$, making summer rains less important to the input of sea salt aerosols to the watersheds.

In contrast to $\mathrm{Na}^{+}$and $\mathrm{Cl}^{-}$, the differences in topographic position and distance to the ocean between $\mathrm{A} 1$ and $\mathrm{F} 2$ seemed to have a limited effect on $\mathrm{SO}_{4}^{2-}$ deposition. Many studies reported significant contributions of longrange-transported $\mathrm{S}$ and $\mathrm{N}$ from eastern China to Taiwan via the northeast monsoon (Lin et al., 2005; Junker et al., 2009). Because A1 is on the windward side of the northeast monsoon, it may experience a higher input of pollutants from long-range transport than F2, which is on the leeward side. The lack of significant differences in $\mathrm{SO}_{4}^{2-}$ between the two watersheds suggest that the two watersheds are too close to show differential influences of pollutants that are transported from sources several hundred kilometers away.

\subsection{Landscape configuration and streamwater chemistry}

The large differences in $\mathrm{NO}_{3}^{-}$concentration and flux between F1 and A1, A2 highlight the role of landscape configuration on streamwater chemistry. Both A1 and A2 are subwatersheds of F1; however, the influence of tea plantation on A1 and $\mathrm{A} 2$ largely dissipated as water entered into forested $\mathrm{F} 1$. Specifically, the concentration of $\mathrm{NO}_{3}^{-}$was $70 \%$ lower at $\mathrm{F} 1$ than at $\mathrm{A} 1$ and $\mathrm{A} 2$. Comparing to the difference in concentration and flux of $\mathrm{NO}_{3}^{-}$between $\mathrm{F} 1$ and $\mathrm{F} 2(<30 \%)$, that between $\mathrm{F} 1$ and $\mathrm{A} 1, \mathrm{~A} 2$ is striking (>300\%; Fig. 2). Thus, by constraining agricultural activities away from the main stream and maintaining natural cover of its watershed, the impact of agriculture on nutrient enrichment could be reduced. Our result confirmed the importance of landscape configuration on streamwater chemistry (Dillon and Molot, 1997; Johnson et al., 1997; Palmer et al., 2004).

\section{4 $\mathrm{N}$ and $\mathrm{P}$ output from agriculture}

The per-hectare output of $\mathrm{N}$ from tea plantations reported here $\left(450 \mathrm{~kg} \mathrm{ha}^{-1} \mathrm{yr}^{-1}\right)$ is extraordinary high compared to those reported for many agricultural watersheds around the globe. For example, a study from the Baltimore Ecosystem Study reported an annual output of $\mathrm{NO}_{3}-$ $\mathrm{N}$ at $13-20 \mathrm{~kg} \mathrm{ha}^{-1} \mathrm{yr}^{-1}$ for a $7.8 \mathrm{ha}$ watershed that is completely covered by agricultural lands and has gentle slopes (Groffman et al., 2004). For the four watersheds that were $30-40 \%$ covered by row crops and received fertilization at $50-70 \mathrm{~kg} \mathrm{Nha}^{-1} \mathrm{yr}^{-1}$ in the southeastern coastal plain of the US, nutrient output through streamflow was $<6 \mathrm{~kg} \mathrm{Nha}^{-1} \mathrm{yr}^{-1}$ (Lowrance et al., 1985). In the Great Barrier Reef, Australia, total output via streamflow was approximately $5 \mathrm{~kg} \mathrm{ha}^{-1} \mathrm{yr}^{-1}$ for $\mathrm{NO}_{3}-\mathrm{N}$ from a watershed with $29 \%$ of the land covered by pasture and $14 \%$ by crop lands (Hunter and Walton, 2008).

High $\mathrm{N}$ output from agricultural lands is probably common in Taiwan and other regions under intensive fertilizer use. It has been reported that over-fertilization is common in Japan, Korea, and Taiwan, and despite an estimated 23$63 \%$ over-fertilization the use of fertilizers is still increasing in the region (Ahmed, 1996). In the Danshui River of northeastern Taiwan, the output of dissolved inorganic $\mathrm{N}$ ranged from $3 \mathrm{~kg} \mathrm{ha}^{-1} \mathrm{yr}^{-1}$ in relatively pristine headwaters covered mostly by natural forests to $100 \mathrm{~kg} \mathrm{ha}^{-1} \mathrm{yr}^{-1}$ in a pop- 
ulated estuary (Lee et al., 2014; Shih et al., 2015). In humid southeastern China, $\mathrm{N}$ output from a watershed with $17.5 \%$ of agricultural lands, steep slopes (the watershed has a mean slope of $21 \%$ and the site is located in the hilly upstream region), and very heavy application of $\mathrm{N}$ fertilizers (300-1000 $\mathrm{kg} \mathrm{ha}^{-1} \mathrm{yr}^{-1}$ ) reached $73 \mathrm{~kg} \mathrm{ha}^{-1} \mathrm{yr}^{-1}$ (Chen et al., 2008), approximately the same magnitude as those reported here. Our study clearly demonstrated that high application of fertilizers in regions with high rainfall and steep slopes could lead to an extremely high output of $\mathrm{N}$ and, therefore, eutrophication risk for downstream watersheds. The misconception that heavy fertilization leads to high economic profit has resulted in the popular practice of heavy fertilization in tea plantations, commonly at a level similar to or higher than that in our study site $\left(740 \mathrm{~kg} \mathrm{~N} \mathrm{ha}^{-1} \mathrm{yr}^{-1}\right)$. For example, conventional $\mathrm{N}$ fertilization in tea plantations is approximately $1100 \mathrm{~kg} \mathrm{ha}^{-1} \mathrm{yr}^{-1}$ in Japan, which is more than twice the suggested amount with the same tea yield (Oh et al., 2006).

In contrast to $\mathrm{N}$, most of the $\mathrm{P}$ fertilizer was retained within the watershed or transported in particulate form so that dissolved $\mathrm{P}$ only accounts for a small proportion of the input. In most agricultural watersheds, the majority ( $>90 \%$ ) of $\mathrm{P}$ leaves the watersheds in particulate form (Smith et al., 1991), and the loss in dissolved form (i.e., $\mathrm{PO}_{4}^{3-}$ ) through runoff is relatively minor (Brady and Weil, 1999). Thus, while the dissolved form of $\mathrm{P}$ could respond to land use changes, a complete $\mathrm{P}$ budget at watershed scale still requires reliable estimates on the particulate $P$.

\subsection{Watershed $\mathrm{N}$ fluxes}

The $72 \% \mathrm{~N}$ retention at $\mathrm{F} 2$ is likely an underestimate because the input from biological $\mathrm{N}$ fixation (BNF) was not included in the calculation. Based on a recent synthesis (Sullivan et al., 2014), BNF in tropical forests is not as high as previously reported and, on average, is slightly less than $10 \mathrm{~kg} \mathrm{ha}^{-1} \mathrm{yr}^{-1}$ for secondary forests. Thus, adding BNF to $\mathrm{N}$ input could increase the $\mathrm{N}$ retention ratio at $\mathrm{F} 2$ (assuming a BNF of $10 \mathrm{~kg} \mathrm{ha}^{-1} \mathrm{yr}^{-1}$, the $\mathrm{N}$ retention ratio at $\mathrm{F} 2$ would increase from 72 to $81 \%$ ). The high $\mathrm{N}$ retention ratio of $\mathrm{F} 2$ suggests that the secondary natural forest is probably still growing. In contrast, because $\mathrm{N}$ fertilizers were applied at rates that are 1 order of magnitude greater than $\mathrm{BNF}$ at $\mathrm{A} 1$, and high $\mathrm{N}$ fertilization is known to negatively affect BNF (Sanginga et al., 1989; Fuentes-Ramírez et al., 1999), adding BNF to nutrient input has little effect on the $\mathrm{N}$ retention ratio at $\mathrm{A} 1$ (assuming a BNF of $10 \mathrm{~kg} \mathrm{ha}^{-1} \mathrm{yr}^{-1}$, the $\mathrm{N}$ retention ratio at $\mathrm{A} 1$ would increase from 35 to $37 \%$ ).

In addition to $\mathrm{BNF}$, the calculation of the $\mathrm{N}$ retention ratio did not take into account the loss through volatilization and denitrification. Because it rains frequently at the FRW, soil moisture is likely high throughout the year and, consequently, $\mathrm{N}$ loss through denitrification could be substantial. In addition, because fertilizers are applied in solid form, volatilization of $\mathrm{NH}_{3}$ could also be high. Thus, if both denitrification and volatilization are taken into account, the $\mathrm{N}$ retention ratio at $\mathrm{A} 1$ is even lower. The return of $\mathrm{N}$ back to the atmosphere through denitrification and volatilization helps explain the higher atmospheric $\mathrm{N}$ deposition at $\mathrm{A} 1$ than at F2. The low retention ratio and the resulting high leaching loss of $\mathrm{N}$ at A1 impose a major threat to the streamwater quality that could lead to reservoir eutrophication.

Surprisingly, from our construction of the $\mathrm{N}$ fluxes, the loss of $\mathrm{N}$ through the annual harvest $\left(25 \mathrm{~kg} \mathrm{ha}^{-1} \mathrm{yr}^{-1}\right)$ at A1 approximately equals the annual atmospheric deposition $\left(26 \mathrm{~kg} \mathrm{ha}^{-1} \mathrm{yr}^{-1}\right.$ ), of which only a small portion should have come from fertilizers (atmospheric $\mathrm{N}$ deposition at $\mathrm{F} 2$ is only $8 \mathrm{~kg}$ lower than at A1, suggesting that less than $8 \mathrm{~kg}$ of atmospheric $\mathrm{N}$ deposition could potentially come from fertilizers). In other words, to maintain the current harvest, not much $\mathrm{N}$ fertilization is actually required, and most of the $173.7 \mathrm{~kg} \mathrm{~N} \mathrm{ha}^{-1} \mathrm{yr}^{-1}$ from fertilization is simply lost through hydrological process (i.e., leaching) to the streams and the Feitsui Reservoir and/or returned to the atmosphere, both of which could have negative environmental impacts. Our construction of the element fluxes clearly showed that the $\mathrm{N}$ fertilizers are applied at rates that are neither ecologically nor economically sound, and such excessive fertilization may cause fundamental changes in watershed nutrient cycling (Fig. 4).

\section{Conclusions}

Agricultural and forested watersheds in tropical/subtropical mountains could have distinct patterns of nutrient cycling. Even a moderate proportion of tea plantation cover (17$22 \%$ ) in mountain watersheds, when in combination with steep slopes and high precipitation, could lead to much higher ion concentrations in both streamwater (nutrient output) and rainwater (nutrient input) and much lower $\mathrm{N}$ retention ratios at watershed scale. Thus, mountain watersheds may be particularly vulnerable to agricultural expansion.

Topographic control is important in nutrient leaching from mountain watersheds, particularly for ions that are rich in soils, such as $\mathrm{SO}_{4}^{2-}, \mathrm{Ca}^{2+}$, and $\mathrm{Mg}^{2+}$.

Proper spatial configuration of agricultural lands in mountain watersheds can mitigate the impact of agriculture on $\mathrm{NO}_{3}^{-}$output by $70 \%$, thus reducing the risk of eutrophication for streams and lakes.

The contribution of tea plantations to the $\mathrm{N}$ output in streamwater for one of the studied watersheds (i.e., A1) is estimated at approximately $450 \mathrm{~kg} \mathrm{~N} \mathrm{ha}^{-1} \mathrm{yr}^{-1}$. This level of fertilization exceeds previous reports around the globe and can only be matched in magnitude by one study in China where fertilizers were excessively applied.

The conservative construction of the $\mathrm{N}$ fluxes for the watersheds indicates over-fertilization at one of the studied watersheds (i.e., A1), which likely resulted in leaching of $\mathrm{N}$ and 
additional loss of $\mathrm{N}$ to the atmosphere via volatilization and denitrification.

Acknowledgements. This research was supported by grants from the National Science Council of Taiwan (101-2116-M-003-003-, 102-2116-M-003-007-). We thank Craig Martin for proofreading this manuscript.

Edited by: M. Hrachowitz

\section{References}

Ahmed, S.: Agriculture-fertilizer interface in the Asia and Pacific region: issues of growth, sustainability, and vulnerability, Extension Bulletin, Food and Fertilizer Technology Center, Taipei, Taiwan, 1996.

Allan, J. D.: Landscape and riverscapes: the influence of land use on stream ecosystems, Annu. Rev. Evol. System., 35, 257-284, 2004.

APHA: Standard Methods for the Examination of Water and Wastewater, 21th Edn., American Public Health Association, American Water Works Association, Water Environment Federation, Washington, D.C., 2005.

Brady, N. C. and Weil, R. R.: The Nature and Properties of Soils, 12th Edn., Prentice Hall, New York, USA, 881 pp., 1999.

Brouwer, J. and Powell, J. M.: Increasing nutrient use efficiency in West-African agriculture: the impact of micro-topography on nutrient leaching from cattle and sheep manure, Agr. Ecosyst. Environ., 71, 229-239, 1998.

Brown, S. and Shrestha, B.:Market-driven land-use dynamics in the middle mountains of Nepal, J. Environ. Manage., 59, 217-225, 2000.

Chang, C. H., Wen, C. G., Huang, C. H., Chang, S. P., and Lee, C. S.: Nonpoint source pollution loading from an undisturbed tropic forest area, Environ. Monitor. Assess., 146, 113-126, 2008.

Chang, S. P. and Wen, C. G.: Changes in water quality in the newly impounded subtropical Feitsui Reservoir, Taiwan, J. Am. Water Resour. Assoc., 33, 343-357, 1997.

Chen, N., Hong, H., Zhang, L., and Gao, W.: Nitrogen sources and exports in an agricultural watershed in Southeast China, Biogeochemistry, 87, 169-179, 2008.

Chen, Z. Y.: Studies on the vegetation of the Machilus-castanopsis forest zone in northern Taiwan, J. Exp. Forest Nat. Taiwan Univers., 7, 127-146, 1993.

Chiueh, P. T., Wu, H. T., and Lo, S. L.: Seasonal water quality trends in the Feitsui Reservoir watershed, Taiwan, World Academy of Science, Engineering and Technology, 5, 372-375, 2011.

Chou, W. S., Lee, T. C., Lin, J. Y., and Yu, S. L.: Phosphorus load reduction goals for Feitsui Reservoir Watershed, Taiwan, Environ. Monit. Assess., 131, 395-408, 2007.

Dillon, P. J. and Molot, L. A.: Effect of landscape form on export of dissolved organic carbon, iron, and phosphorus from forested stream catchments, Water Resour. Res., 33, 2591-2600, 1997.

Ding, S. B., Lin, T. C., Chan, S. C., Huang, J. L., and Lin, N. H.: Precipitation chemistry at a high elevation forest in central Taiwan, J. Forest Res., 16, 438-445, 2011.
Evans, D. M., Schoenholtz, S. H., Wigington Jr., P. J., Griffith, S. M., and Floyd, W. C.: Spatial and temporal patterns of dissolved nitrogen and phosphorus in surface waters of a multi-land use basin, Environ. Monit. Assess., 186, 873-887, 2014.

FAO - Food and Agriculture Organization: Fertilizer use by crop in Taiwan Province of China, Rome, 2002.

Fuentes-Ramírez, L. E., Caballero-Mellado, J., Sepúlveda, J., and Martínez-Romero, E.: Colonization of sugarcane by Acetobacter diazotrophicus is inhibited by high $\mathrm{N}$-fertilization, FEMS Microbiol. Ecol., 29, 117-128, 1999.

Gaynor, J. D. and Findlay, W. I.: Soil and phosphorus loss from conservation and conventional tillage in corn production, J. Environ. Qual., 24, 734-741, 1995.

Groffman, P. M., Law, N. L., Belt, K. T., Band, L. E., and Fisher, G. T.: Nitrogen fluxes and retention in urban watershed ecosystems, Ecosystems, 7, 393-403, 2004.

Hsieh, C. D. and Yang, W. F.: Study of total maximum daily load and nonpoint source pollution control strategies for reservoir watershed, Pract. Period. Hazard. Tox. Radioact. Waste Manage., 10, 134-143, 2006.

Hsieh, C. D. and Yang, W. F.: Optimal nonpoint source pollution control strategies for a reservoir watershed in Taiwan, J. Environ. Manage., 85, 908-917, 2007.

Huang, J.-C., Lee, T.-Y., Kao, S.-J., Hsu, S.-C., Lin, H.-J., and Peng, T.-R.: Land use effect and hydrological control on nitrate yield in subtropical mountainous watersheds, Hydrol. Earth Syst. Sci., 16, 699-714, doi:10.5194/hess-16-699-2012, 2012.

Huang, S. N.: The fertilization of root crops in Taiwan, Proceeding of A Symposium on Root Crop Yield Improvement, Processing and Utilization in Taiwan, Taichung, Taiwan, 163-169, 1994.

Hunter, H. M. and Walton, R. S.: Land-use effects on fluxes of suspended sediment, nitrogen and phosphorus from a river catchment of the Great Barrier Reef, Australia, J. Hydrol., 356, 131146, 2008.

Jodha, N. S., Banskota, M., and Partap, T.: Strategies for sustainable development of mountain agriculture: An overview, in: Sustainable Mountain Agriculture: Perspectives and Issues, Vol. 1, edited by: Jodha, N. S., Banskota, M., and Partap, T., Oxford \& IBH Publishing Co. Pvt. Ltd., New Delhi, 3-40, 1992.

Johnes, P. J.: Evaluation and management of the impact of land use change on the nitrogen and phosphorus load delivered to surface waters: the export coefficient modelling approach, J. Hydrol., 183, 323-349, 1996.

Johnson, C. E., Driscol, C. T., Siccama, T. G., and Likens, G. E.: Element fluxes and landscape position in a northern hardwood forest watershed ecosystem, Ecosystems, 3, 159-184, 2000.

Johnson, L., Richards, C., Host, G., and Arthur, J.: Landscape influences on water chemistry in Midwestern stream ecosystems, Freshwater Biol., 37, 193-208, 1997.

Junker, C., Wang, J. L., and Lee, C. T.: Evaluation of the effect of long-range transport of air pollutants on coastal atmospheric monitoring sites in and around Taiwan, Atmos. Environ., 4, 3374-3384, 2009.

Kleinman, P. J. A., Sharpley, A. N., McDowell, R. W., Flaten, D. N., Buda, A. R., Tao, L., Bergstrom, L., and Zhu, Q.: Managing agricultural phosphorus for water quality protection: principles for progress, Plant Soil, 349, 169-182, 2011. 
Kuo, C. W. and Lee, C. T.: Trend analysis of water quality in the upper watershed of the Feitsui Reservoir, J. Geogr. Sci., 38, 111$128,2004$.

Lee, T.-Y., Huang, J.-C., Kao, S.-J., and Tung, C.-P.: Temporal variation of nitrate and phosphate transport in headwater catchments: the hydrological controls and land use alteration, Biogeosciences, 10, 2617-2632, doi:10.5194/bg-10-2617-2013, 2013.

Lee, T.-Y., Shih, Y.-T., Huang, J.-C., Kao, S.-J., Shiah, F.-K., and Liu, K.-K.: Speciation and dynamics of dissolved inorganic nitrogen export in the Danshui River, Taiwan, Biogeosciences, 11, 5307-5321, doi:10.5194/bg-11-5307-2014, 2014.

Li, K. C. and Yeh, M. C.: Nonpoint source pollution potential index: a case study of the Feitsui Reservoir watershed, Taiwan, J. Chinese Inst. Eng., 27, 253-259, 2004.

Lin, C. Y., Liu, S. C., Chou, C. C. K., Huang, S. J., Liu, C. M., Kuo, C. H., and Yound, C. Y.: Long-range transport of aerosols and their impact on the air quality of Taiwan, Atmos. Environ., 39, 6066-6076, 2005.

Lin, T. C., Hamburg, S. P., King, H. B., and Hsia, Y. J.: Throughfall patterns in a subtropical rain forest of northeastern Taiwan, J. Environ. Qual., 29, 1186-1193, 2000.

Liu, W. C., Chen, H. H., Hsieh, W. H., and Chang, C. H.: Linking watershed and eutrophication modeling for the Shihmen Reservoir, Taiwan, Water Sci. Technol., 54, 39-46, 2006.

Lowrance, R. R., Leonard, R. A., Asmussen, L. E., and Todd, R. L.: Nutrient budgets for agricultural watersheds in the southeastern coastal plain, Ecology, 66, 287-296, 1985.

Lu, R. S., Lo, S. L., and Hu, J. Y.: Analysis of reservoir water quality using fuzzy synthetic evaluation, Stoch. Environ. Res. Risk A., 13, 327-336, 1999.

Murty, D., Kirschbaum, M. U., Mcmurtrie, R. E., and Mcgilvray, H.: Does conversion of forest to agricultural land changes soil carbon and nitrogen? a review of the literature, Global Change Biol., 8, 105-123, 2002.

Muscutt, A. D., Harris, G. L., Bailey, S. W., and Davies, D. B.: Buffer zones to improve water quality: a review of their potential use in UK agriculture, Agr. Ecosyst. Environ., 45, 59-77, 1993.

Oh, K., Kato, T., Li, Z. P., and Li, F. Y.: Environmental problems from tea cultivation in Japan and a control measure using calcium cyanamide, Pedosphere, 16, 770-777, 2006.

Omernik, J. M.: The influence of land use on stream nutrient levels, USEPA Ecological Research Series EPA-60013-76-014, US Environmental Protection Agency, Corvallis, OR, 1976.

Palmer, S. M., Driscoll, C. T., and Johnson, C. E.: Long-term trends in soil solution and stream water chemistry at the Hubbard Brook Experimental Forest: relationship with landscape position, Biogeochemistry, 68, 51-70, 2004.

Sanginga, N., Kulongoy, K., and Ayanaba, A.: Nitrogen fixation of field-inoculated Leucaena leucocephala (Lam.) de Wit estimated by the $15 \mathrm{~N}$ and the difference methods, Plant Soil, 117, 269-274, 1989.
Sarmiento, F. O. and Frolich, L. M.: Andean cloud forest tree lines, Mount. Res. Develop., 22, 278-287, 2002.

Sharpley, A. N., Kleinman, P. J. A., McDowell, R. W., Gitau, M., and Bryant, R. B.: Modeling phosphorus transport in agricultural watersheds: processes and possibilities, J. Soil Water Conserv., 57, 425-439, 2002.

Shih, Y.-T., Lee, T.-Y., Huang, J.-C., Kao, S.-J., Liu, K.-K., and Chang, F.-J.: Inverse isolation of dissolved inorganic nitrogen yield for individual land-uses from mosaic land-use patterns within a watershed, Hydrol. Earth Syst. Sci. Discuss., 12, 449487, doi:10.5194/hessd-12-449-2015, 2015.

Smith, S. J., Sharpley, A. N., Naney, J. W., Berg, W. A., and Jones, O. R.: Water quality impacts associated with wheat culture in the Southern Plains, J. Environ. Qual., 20, 244-249, 1991.

Sullivan, B. W., Smith, W. K., Townsend, A. R., Nasto, M. K., Reed, S. C., Chazdon, R. L., and Cleveland, C. C.: Spatially robust estimates of biological nitrogen $(\mathrm{N})$ fixation imply substantial human alternation of the tropical $\mathrm{N}$ cycle, P. Natl. Acad. Sci., 111, 8101-8106, 2014

Tilman, D., Fargione, J., Wolff, B., D’Antonio, C., Dobson, A., Howarth, R., Schindler, D., Schlesinger, W. H., Simberloff, D., and Swackhamer, D.: Forecasting agriculturally driven global environmental change, Science, 292, 281-284, 2001.

Tokuchi, N., Takea, H., Yoshida, K., and Iwatsubo, G.: Topographical variation in a plant-soil system along a slope on Mt. Ryuoh, Japan, Ecol. Res., 14, 361-369, 1999.

Tsai, H. T. and Tsai, Y. J.: Fertilizer record and application in tea farm, Tea Research and Extension Station, Taiwan, 2008.

Tulachan, P. M.: Mountain agriculture in the Hindu Kush-Himalaya, Mount. Res. Develop., 21, 260-267, 2001.

Turtola, E. and Jaakkola, A.: Loss of phosphorus by surface runoff and leaching from a heavy clay soil under barley and grass ley in Finland, Acta Agricult. Scand. B, 45, 159-165, 1995.

Uraiarte, M., Yackulic, C. B., Javier, Y. L., and Arce-Nazario, J. A.: Influence of land use on water quality in a tropical landscape: a multi-scale analysis, Landscape Ecol., 26, 1151-1164, 2011.

van Breemen, N., Burrough, P. A., Velthorst, E. J., van Dobben, H. F., de Wit, T., Ridder, T. B., and Reijnders, H. F. R.: Soil acidification from atmospheric ammonium sulfate in forest canopy throughfall, Nature, 299, 548-550, 1982.

Water Resources Agency: Best Management Practice of Non-point Pollution from Tea Plantation in the Upper Watershed of Feitsui Reservoir, Report \# R9901-0920, Water Resources Agency, Ministry of Economics, Taipei, Taiwan, 2010.

Wu, E. and Kuo, S. L.: Applying a multivariate statistical analysis model to evaluate the water quality of a watershed, Water Environ. Res., 84, 2075-2085, 2012.

Zehetner, F., Vemuri, M. L., Huh, C. A., Kao, S. J., Hsu, S. C., and Chen, Z. S.: Soil and phosphorus resdistribution along a steep tea plantation in Feitsui Reservoir catchment of northern Taiwan, Soil Sci. Plant Nutr., 54, 618-626, 2008. 